\title{
Többdimenziós folyadékkromatográfiás elválasztás alkalmazása biomarker identifikálásban
}

\author{
REZELI Melinda ${ }^{\mathrm{a}}$, KÁRPÁTI Sarolta ${ }^{\mathrm{b}}$, TÍMÁR József ${ }^{\mathrm{c}}$ és MARKO-VARGA György ${ }^{\mathrm{a}, \mathrm{d}, \mathrm{e}^{*}}$ \\ a Clinical Protein Science \& Imaging, Dept. of Biomedical Engineering, Lund University, BMC D13, 221 84, Lund, Sweden \\ ${ }^{b}$ Bör-, Nemikórtani és Böronkológiai Klinika, Semmelweis Egyetem, Mária u. 41., 1085, Budapest, Magyarország \\ c II.sz. Pathologiai Intézet, Semmelweis Egyetem, Üllöi út 93., 1091 Budapest, Magyarország \\ ${ }^{d}$ Center of Excellence in Biological and Medical Mass Spectrometry, Lund University, BMC D13, 221 00, Lund, Sweden \\ ${ }^{e}$ First Department of Surgery, Tokyo Medical University, 6-7-1 Nishishinjiku Shinjiku-ku, 160-0023, Tokyo, Japan
}

\section{Bevezetés}

A klinikai minták értékes forrást jelentenek olyan vizsgálatok számára, amelyek különböző betegségek kialakulásában szerepet játszó és azokat irányító tényezők, folyamatok feltárására irányulnak 1. A klinikai mintákban megtalálható biológiai és kémiai markerek értékes információt szolgáltatnak a vizsgált alany egészségi állapotáról. Ezen adatokat a hagyományos vizsgálati eredményekkel kombinálva, nagymértékben elősegíthető az optimális kezelési eljárás kiválasztása az orvosok számára 2. A mintafeldolgozás, tárolás és kezelés megannyi lépését kell megérteniük, és szigorúan követniük a kutatási és fejlesztési tevékenységet végzőknek. Ezen munkafolyamatok és az adatok kezelésének standardizálása a humán minták minőségmegőrzésén túl elősegíti a mintát szolgáltató alany védelmét szolgáló morális és jogi keretek jobb megértését a mintagyüjtés helyétől függetlenül. A tudományos közösség nagy erőfeszítéseket tesz a különböző biobankokban folyó tevékenységek (biológiai minták és adatok tárolása, ill. kezelése, szeparációs módszerek) egységesítésének és standardizálásának érdekében, beleértve a betegtájékoztatást, beleegyezési nyilatkozatot és a tanulmányok intézményi engedélyeztetését ${ }^{3-4}$.

A nagyszámú alany bevonásával végzett tanulmányok jelentősen gyarapítják a különböző betegségekkel kapcsolatos ismereteinket. Az ilyen vizsgálatokból nyert adatok értékes tudásbázist képeznek a jövő betegségmodelljeinek megalkotásához, illetve a szervezetben zajló kóros folyamatok alaposabb megértéséhez ${ }^{5}$.

\section{Mintakollekciók - Biobankok}

A fehérje biomarkerek identifikálásában az utóbbi időben egyre nagyobb hangsúlyt kaptak a proteomikai módszerek. A folyamatos technológiai fejlődés ellenére az újonnan felfedezett biomarker jelöltek diagnosztikus értéke viszonylag csekély. Gyakran a nem megfelelően kontrollált mintavételi és tárolási körülmények tehetők felelőssé azért, hogy a korábban ígéretesnek tűnő markerek nem minden esetben váltják be a hozzájuk füzött reményeket. A következő generációs diagnosztikai eljárások és kezelési módszerek kifejlesztésének elengedhetetlen feltétele a legmagasabb minőségi követelményeknek megfelelő mintakollekciók megléte ${ }^{6-7}$.
Részletes klinikai adatok és mintakollekciók egységes rendszerének létrehozása olyan stratégiai befektetés amelyből nem csupán a jövő egészségügyi ellátórendszere profitálhat, de a jelenleg folyamatban levő nagy léptékü genetikai és proteomikai kutatások során is segítséget nyújt ${ }^{8}$. A modern biobankok nem csupán kiváló minőségű vér- és szövetmintát szolgáltatnak, de egységes rendszerben kezelt adatállományaik nagyban hozzájárulnak a kutatások sikeréhez. Ezen minták klinikai döntéshozatalban betöltött szerepét jelentősen befolyásolja azok minősége és integritása. Napjainkban folyamatos erőfeszítések zajlanak olyan eljárások kifejlesztésére, amelyek nemcsak a jelen de a jövő biobankjaival szemben támasztott követelményeknek is igyekeznek megfelelni, úgy a minta minőségét, mint integritását illetően ${ }^{9-10}$.

\section{Proteomika a klinikai minták vizsgálatában}

A proteomika a szervezetben megtalálható fehérjék azonosítását, mennyiségi meghatározását, azok időbeli és térbeli eloszlásának vizsgálatát, valamint biológiai funkcióinak feltérképezését foglalja magában ${ }^{11}$. A proteomikai kutatások meghatározó eszköze a tömegspektrometria (MS), javarészt folyadékkromatográfiás és/vagy gélelektroforézises elválasztással kombinálva. A tömegspektrometria az utóbbi években ugrásszerü fejlődésen ment keresztül, ezáltal hatékony eszközzé vált a fehérjék egyértelmű azonosítására és mennyiségi meghatározására komplex biológiai mintákban ${ }^{12}$. A nagyszabású, modern készülékekkel végzett fehérjeszekvenálási elemzések alacsony mennyiségben jelenlevő fehérjék vizsgálatára is alkalmasak - akár még összetett mintákban is -, lehetővé téve ezzel olyan specifikus fehérjeformák (proteoforms) azonosítását is, amelyek meghatározott betegségekhez köthetők.

Az egyes fehérjék és azok bizonyos módosulatainak (pl. poszt-transzlációs módosulat, mutáns változat) mennyiségi meghatározása és azok időbeli változásainak elemzése egyes betegségek különböző fázisaiban, hozzájárul a betegségek háttérben zajló biológiai folyamatok jobb megértéséhez.

\footnotetext{
* Föszerző. Tel.:+46-46-222 3721; e-mail: gyorgy.marko-varga@bme.lth.se.
} 
A

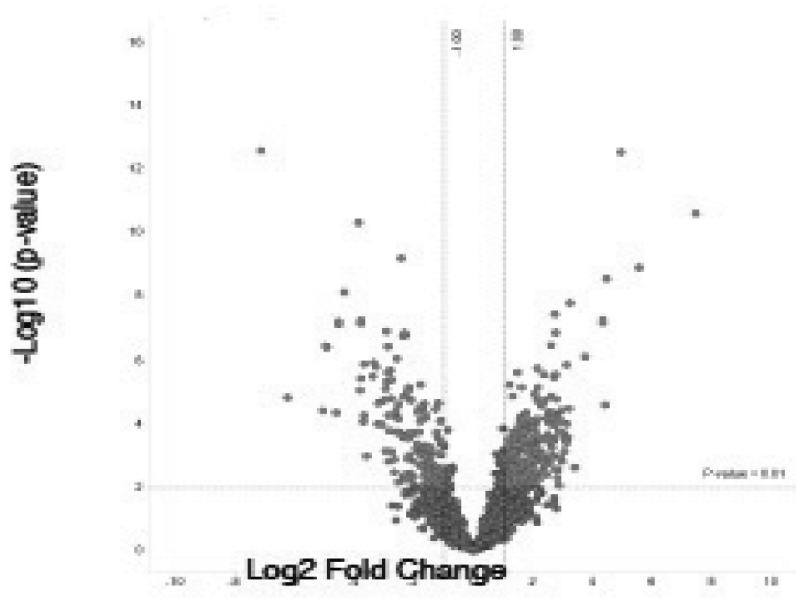

B

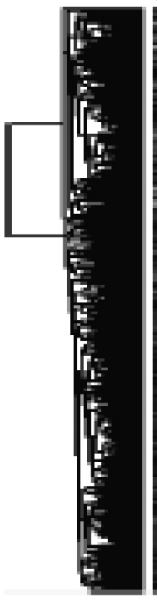

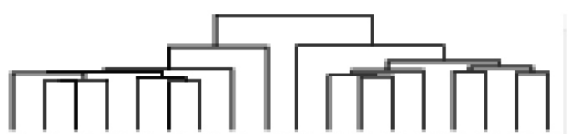

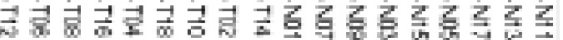

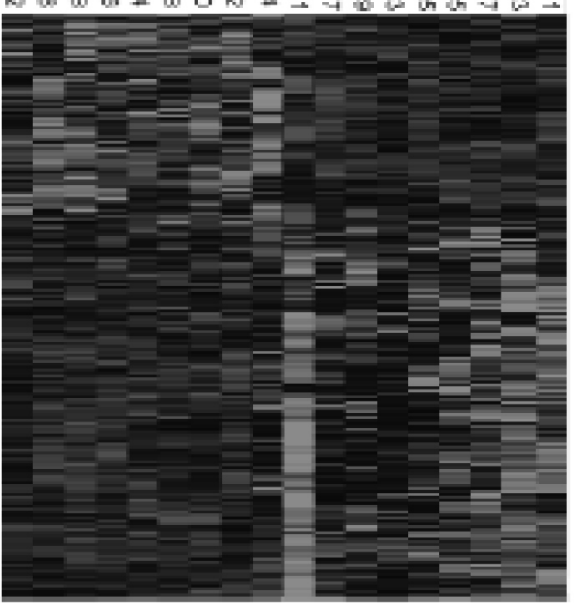

1. ábra. Eltérően expresszálódó fehérjék Volcano-plot (A) és Heatmap (B) analízise kontroll és tumorszövetben.

Manapság a biomarker kutatásban leggyakrabban használt fehérjeanalitikai módszer az úgynevezett „shotgun” vagy „bottom-up” eljárás. Ebben a megközelítésben a cél nyitott, azaz a vizsgálatnak nincs elöre meghatározott célfehérjéje; az ilyesfajta globális fehérjeexpressziós analízisek elnevezésére gyakran használják a teljes proteom szekvenálás (whole proteome sequencing) ill. ,deep mining” kifejezéseket is. A „shotgun” eljárás során a fehérjéket specifikus proteázok (fehérjebontó enzimek) segítségével peptidekre hasítjuk, majd az így kapott peptid elegyet nagy hatékonyságú folyadékkromatográfiás (HPLC) elválasztást követően tömegspektrométer (MS) segítségével analizáljuk. A peptidek azonosítása a tandem tömegspektrumuk (MS/MS) alapján történik speciálisan erre a célra kifejlesztett szoftverek segítségével, melyek a kísérletesen előállított spektrumokat elméletileg generált spektrum adatbázisokkal vetik össze. Az így azonosított peptid szekvenciák alapján meghatározható a minta fehérje-összetétele.

Az utóbbi időben egyre nagyobb figyelem irányul a globális fehérjeexpressziós analízissel foglalkozó tanulmányok felé, hiszen a közelmúlt kutatásai jelentős számú fehérje biomarker jelöltet azonosítottak elsősorban rákbetegségekben (1. ábra), de más pl. neurológiai, kardiológiai megbetegedésekben is ${ }^{13}$. Ezen biomarker jelöltek egy részének szerepe általánosabb és a tumorbiológiához köthetö, míg más részük sokkal specifikusabb és csak bizonyos ráktípusokhoz, ill. azok adott geno- vagy fenotípusához kapcsolható.

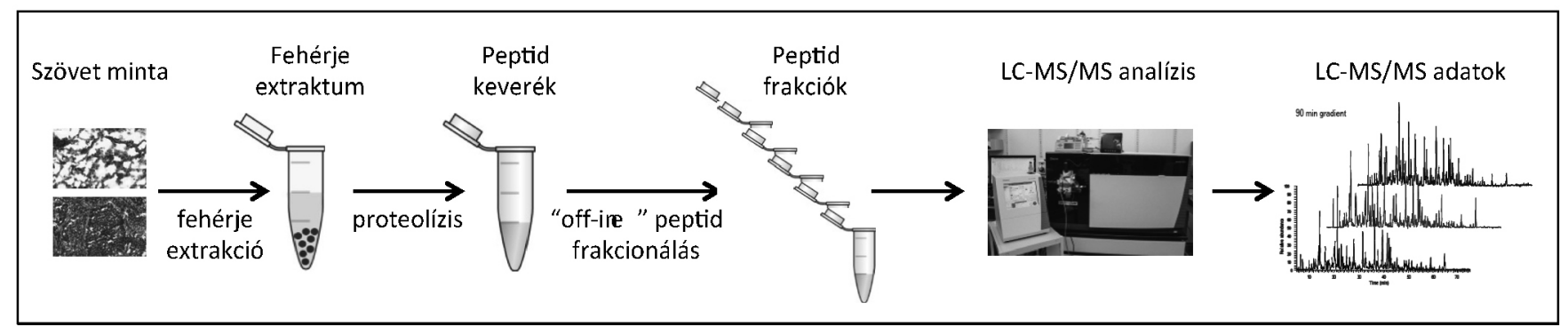

2. ábra. Két dimenziós LC-MS/MS vizsgálat folyamatábrája.

Még a legfejlettebb müszerekkel végzett hagyományos egydimenziós LC-MS/MS vizsgálatok során azonosított fehérjék száma is korlátozott az analizált minta nagyfokú komplexitása miatt 14-15. Az összetett biológiai minták klasszikus módszerekkel történő elemzése során felmerülő nehézségek vezettek az ún. többdimenziós fehérjeazonosítási technológia (MudPIT) kifejlődéséhez, melyben úttörő szerepe volt JR Yates-nek és munkatársainak 16-18. A technika alapja a peptidek kétdimenziós kromatográfiás elválasztása töltés és hidrofobicitás alapján, amit tandem MS analízis követ (2. ábra). A peptidszeparáció első dimenziója során mind kation-, mind anioncserés mechanizmusok alkalmazhatók, amely közvetlenül („on-line”) vagy „off-line” módon kapcsolódhat a következő, általában fordított fázisú kromatográfiás elválasztáshoz. Az ioncsere olyan kromatográfiás elválasztási technika, amely során töltéssel rendelkező molekulák elválasztása történik azok ioncserélő állófázishoz való affinitásuk alapján. Fordított fázisú kromatográfia esetén az alkalmazott állófázis hidrofób, az 
állófázis és a mintamolekulák között hidrofób kölcsönhatás jön létre és az elválasztás az elválasztandó molekulák hidrofobicitás különbségén alapul.

$\mathrm{Az}$ eredmények tükrében megállapítható, hogy az ortogonális elválasztási technikák kombinálásával létrejött multidimenziós elválasztások teljesebb proteom analízist tesznek lehetővé az azonosított peptidek/fehérjék számának növelése által (3. ábra). Az automatizált multidimenziós folyadékkromatográfiás platformok térnyerése egyre nagyobb a proteomikai elemzések során.

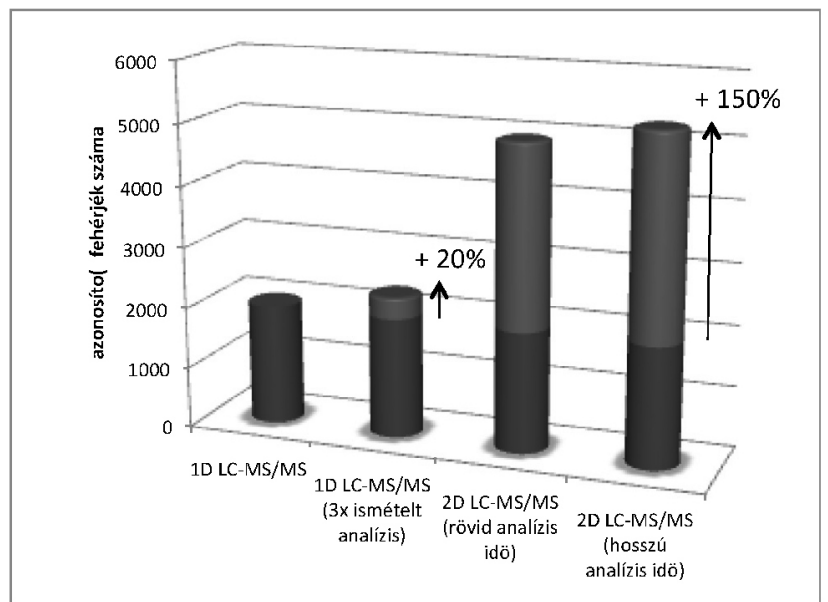

3. ábra. A klasszikus egydimenziós és a kétdimenziós LC-MS/MS vizsgálati eredményeinek összehasonlítása.

\section{Konklúzió}

Jelen kézirat a biobankok szabványosításának kérdéskörét vázolja föl, valamint azon követelményeket taglalja, melyek a jövő klinikai kísérleteinek szükségleteit elégítik ki, különös figyelmet fordítva azon területekre, ahol a proteomika vagy a genomika kiemelkedő jelentőséggel bír. Átfogó képet nyújt arról az új irányvonalról, melyben a bevált gyakorlatok és a hagyományos eljárások mellett a biomarker kutatásból nyert ismereteket és adatokat integrálják az egészségügy széleskörü tapasztalatot és nagy adatmennyiséget igénylő területein. A tárgyalt fejlesztéseket a személyre szabott orvoslás (personalized medicine) eszköztárába tartozó, a betegségeket azok specifikus genoés fenotípusának legmegfelelőbb hatóanyagokkal történő kezelésén keresztül mutatja be, mely módszer már számos fontos betegség terápiájában kiemelkedően hatékonynak bizonyult ${ }^{2,19}$. E terápiás paradigmát egyre több betegséggel összefüggésben alkalmazva egy újfajta megközelítés van kialakulóban, mely a diagnózisról és a terápiáról alkotott képünket is jelentősen megváltoztatja; a precíziós orvoslás (precision medicine) $^{20}$.

\section{Köszönetnyilvánítás}

Jelen munkát az alábbi kutatási alapítványok támogatták: Mrs. Berta Kamprad Foundation, Swedish Foundation for Strategic Research, Vinnova, Ingabritt \& Arne Lundbergs forskningsstiftelse and the National Research Foundation of Korea, funded by the Korean governement (NRF-2015K1A12028365).

\section{Hivatkozások}

1. Eiseman, E.; Bloom, G.; Brower, J.; et al., editors. Case studies of existing human tissue repositories: "best practices" for a biospecimen resource for the genomic and proteomic era. RAND Corp: Santa Monica, 2003.

2. Marko-Varga, G.; Ogiwara, A.; Nishimura, T.; et al. J. Proteome Res. 2007, 6(8), 2925-2935. https://doi.org/10.1021/pr070046s

3. Riegman, P.H.; Morente, M. M.; Betsou, F.; de Blasio, P.; Geary, P.; Marble Arch International Working Group on Biobanking for Biomedical Research. Mol Oncol. 2008, 3 , 213-22 https://doi.org/10.1016/j.molonc.2008.07.004

4. Marko-Varga, G.; Vegvari, A.; Welinder, C.; Lindberg, H.; et al. J. Proteome Res. 2012, 11, 5124-5134 https://doi.org/10.1021/pr300185k

5. Hardy, J., Singleton, A. N Engl J Med 2009, 360:1759-1768 https://doi.org/10.1056/NEJMra0808700

6. Baker, M. Nature, 2012, 486, 141-146 https://doi.org/10.1038/486141a

7. Hewitt, R. E. Curr Opin Oncol. 2011, 23(1), 112-119 https://doi.org/10.1097/CCO.0b013e32834161b8

8. Welinder, C., Jonsson, G., Ingvar, C., Lundgren, L., et al. Clin Transl Med. 2013, 2, 7 https://doi.org/10.1186/2001-1326-2-7

9. Malm, J.; Fehniger, T. E.; Danmyr, P.; Vegvari, A., et al. Journal of proteomics 2013, 95, 38-45 https://doi.org/10.1016/j.jprot.2013.06.035

10. Malm, J.; Végvári, A.; Rezeli, M.; Upton, P.; Danmyr, P.; Nilsson, R.; Steinfelder, E.; Marko-Varga, G. J Proteomics. 2012, 76, 116-24. https://doi.org/10.1016/j.jprot.2012.05.003

11. Anderson, N. L.; Anderson, N. G. Electrophoresis, 1998, 19 (11): 1853-61 https://doi.org/10.1002/elps.1150191103

12. Aebersold, R.; Mann, M. Nature, 2003, 422, 198-207 https://doi.org/10.1038/nature01511

13. Khleif, S. N.; Doroshow, J. H.; Hait, W. N. Clin Cancer Res. 2010, 16, 3299-3318. https://doi.org/10.1158/1078-0432.CCR-10-0880

14. Anderson, N. L.; Anderson, N. G. Mol. Cell. Proteomics, 2002, 1, 845-67 https://doi.org/10.1074/mcp.R200007-MCP200

15. Wang, H.; Chang-Wong, T.; Tang, H.Y.; Speicher, D.W. J. Proteome Res, 2010, 9, 1032-1040. https://doi.org/10.1021/pr900927y

16. McDonald, W.H.; Ohi, R.; Miyamoto, D.T.; Mitchison, T.J.; Yates III, J.R. Int. J. Mass Spectrom. 2002, 219, 245-251. https://doi.org/10.1016/S1387-3806(02)00563-8

17. Washburn, M.P.; Wolters, D.; Yates III, J.R. Nat. Biotechnol. 2001, 19, 242-247. https://doi.org/10.1038/85686

18. Wolters, D.A.; Washburn, M.P.; Yates III, J.R. Anal. Chem. 2001, 73, 5683-5690. https://doi.org/10.1021/ac010617e

19. Margaret, A.; Hamburg, M.A.; Collins, F.S. N Engl J Med. 2010, 363, 301-304 https://doi.org/10.1056/NEJMp1006304

20. Marko-Varga, G.; Fehniger, T.E. J Transl Med 2012, 10(Suppl 2), A48 https://doi.org/10.1186/1479-5876-10-S2-A48 


\section{Multidimensional liquid chromatography in biomarker discovery}

Clinical samples represent a valuable resource for investigating the many factors that drive human biology in various disease settings. Biological and chemical markers that are contained in clinical samples bring important read-outs of health and disease. When these data are combined with such medical evaluation data, it can aid in decision making by physicians on optimal treatment procedures.

There are many steps in sample processing, storage, and management that need to understand and are pursued by R\&D operations. These work flows and integrations provide not only the preservation of the desired analytes in the sample, but also good understanding of the moral and legal framework required for subject protection irrespective of where the samples have been collected. There is a great deal of effort in todays community work to align and standardize both the methodology of protein separation, and storage performed in different biobanks and the necessary frameworks of subject protection including informed consent and institutional review of the studies being performed.

Our knowledge of diseases is being advanced in large population-based studies globally, and the use of data from these epidemiological resources will highly impact our ability to both model and solve disease-related questions in the future.

Mass spectrometry has become a powerful tool for unambiguous identification and quantification of proteins in complex biological samples. Large-scale protein sequencing studies are undertaken to discover protein forms either; i.e. proteoforms that can be linked to disease, and treatment processes. Abundance of proteins has great biological significance and determination of protein expression levels, their post-translational modifications and their interactions in association with disease processes is therefore important. Even with advanced instrumentation, the number of proteins identified with a conventional one-dimensional LC-MS/MS setup is limited by the general complexity of sample proteome. The difficulties when analyzing complex biological samples with shotgun approach led to the development of multidimensional analysis of protein identification technology (MudPIT) pioneered by Yates and colleagues. As the results indicate, orthogonality of MudPIT technology allows for deeper proteome analysis with increased number of identified proteins. Multidimensional liquid chromatography separation systems within automated platforms, where ion-exchange separation mechanisms play a major role are often used in proteomic analyses. 